\title{
MACHINING PROPETIES OF COCONUT PALM WOOD
}

\author{
R. A. Juson ${ }^{1}$
}

\section{SUMMARY}

Kiln dried coconut lumber with 16 percent average moisture content were subjected to five common wood working processes composed of planing, boring, shaping, turning and sanding. Tungsten carbide cutters were used in each process except in sanding where silicon no. 60 sandpaper was employed. The coconut lumber measuring $25 \mathrm{~mm}$ thick by $125 \mathrm{~mm}$ wide by $1.25 \mathrm{~m}$ long have density range of 200 to $900 \mathrm{~kg}$. per cubic meter.

Results revealed that coconut wood can be satisfactorily machined under a variety of machine operations normaUy encountered in commercial manufacturing practice. Machinability of coconut wood sigaificantly improved with higher density regardless of the machining process. The quality of finish depends mainly on the processing method and density of the wood. As with other kinds of wood, excellent surface quality can be achieved with appropriate combination of machine speed and feed rate. In general, coconut wood exhibited fair to excellent machining qualities.

However, the cost of tungsten carbide, its maintenance facilities and the services of highly skilled technicians are limiting factors for small scale wood industries. Tipping or coating standard steel cutters with hard facing material like stellite was proven possible and durable and less expensive requiring ordinary maintenance equipment hence, can be suitably employed for machining coconut wood.

\section{INTRODUCTION}

\section{A. Importance of the Study}

A Phflippine Coconut Authority (PCA) survey conducted in 1979 showed that approximately $3017 \mathrm{o}$ of the 2.8 million hectares of coconut plantation in the Philippines are in their declining years_of production due to increased senflity (Mendoza, 1979), with palms aged 60 years and over. Hence, replanting these senile palms is a major program of the government. The replanting process however, calls for the proper disposal of the old palms to minimize the potential threat of phytosanitary hazards on the newly established plantation. Consequently, conversion of coconut trunks to marketable products has been recognized as the most effective way of disposal. This system will not only provide adequate means of disposing the felled trunks but shall also become an apportunity for the coconut farmers to reatize some unexpected income. Based on the average of 100 trees to be replanted per hectare, about 84 million palms should be replaced with early bearing and high yielding hybrids to improve production. Further assuming that 0.75 cubic meter will be recovered per tree, around 63 million cubic meters of coconut timber will then be available for economic utilization.

Research on timber utilization conducted at Zamboanga Research Center of the Philippine-Coconut Authority has proven that coconut trunks can be sawn, dried and machined to a wide range of wood products such as furniture, parquet and curios. However, utilization of coconut wood for the said end-use has been frustrated by the rapid dulling of ordinary steel cutting knives associated with the coarse and abrasive grain of the wood. Observations, on the furnitures manufactured at PCA-ZRC for demonstration showed that the surface of the seasoned materials appeared uneven due to the presence of small broken fibers and wear of the parenchyma tissues.

\footnotetext{
${ }^{1}$ Science Research Specialist, Timber Utilization Division, Philippine Coconut Authority, Zamboanga Research Center, P.O. Box 356, Zamboanga Ctty, Philippines.
} 
Knowing the problem and its importance to the wood-using industry, this study was conducted to foster applicable information on the machining properties of coconut wood.

\section{B. Review of Literature}

The coconut stem wood consists of scattered vascular bundles set in a matrix of more or less spherical parenchyma cells. A typical stern at one meter height would, have about 10 bundles $/ \mathrm{cm}^{2}$ in the central portion and about 50 bundles $/ \mathrm{cm}^{2}$ near the outside (Meylan, 1978). The wood cells are, not dead as in normal forest trees and the walls continue to increase in thickness so that by the time the palm matures the density in these two regions can be as high as 250 to $900 \mathrm{~kg} / \mathrm{m}^{3}$ (Mcquire, 1979).

Coconut wood has no distinct grain pattern in relation to periodic radial growth so the material will dry uniformly and with out cross-sectional distortion. Lateral shrinkage in any direction is less than 3 percent when drying from green to 12 percent moisture content. Shrinkage in low density is accentuated by collapse which is not recoverable by subsequent re-conditioning particularly when the basic density of the material decreases below $350 \mathrm{~kg}$. per cubic: meter. Collapse is severe with those of basic: density below $200 \mathrm{~kg}$. per cubic: meter and usage of the material is very limited (Kininmonth, 1976).

Technical informations on mechanical. properties indicated that medium to high density coconut wood can adequately withstand the type of loading required in general. furniture applications (Tamolang, et al, 1976). Accordingly, only the material in the outer portion of the butt log can be considered for making furnitures and other end-uses (Alston, 1976). The quality of small dimension pieces was uniformly high due to the absence of knots (Mcquire, 1979). Different species/densities greatly vary on their behavior under cutting tools, hence, the need to determine their suitability for such use as cabinet work and other products where favorable machining properties are essential to good finish (ASTM, 1964). Machining tests on coconut wood showed that the wear on the cutting edge of high speed steel knives was in excess of $1.5 \mathrm{~mm}$ after machining 200 meters of $15 \mathrm{~cm}$ wide boards (Bergseng, 1976).

\section{Objectives and Scope of the Study}

This study was conducted to detennine the machining properties of coconut wood when subjected to common woodworking processes by planing, boring, shaping, turning and sanding coconut lumber. The materials; used were kiln dried lumber having density range of 200 to $900 \mathrm{~kg}$. per cubic meter.

\section{Time and Place of Study}

The study was conducted in August, 1981'to February, 1982 at the Zamboanga Research Center, Philippine Coconut Authority, San Ramon, Zamboanga City.

\section{MATERIALS AND METHODS}

\section{A. Materials}

Tungsten carbide cutters, silicon no. 60 sandpaper and 450 pieces of kiln dried coconut lumber with 16 percent average moisture content were used in this study. The lumber measuring 25 $\mathrm{mm}$ thick by $125 \mathrm{~mm}$ wide by $1.25 \mathrm{~m}$ long were classified to low $\left(200-399 \mathrm{~kg} / \mathrm{m}^{3}\right)$, medium (400-599 $\left.\mathrm{kg} / \mathrm{m}^{3}\right)$ and high $\left(600-900 \mathrm{~kg} / \mathrm{m}^{3}\right)$ density groups respectively, with 150 samples in each group. 
The woodworking machines consist of: a single-surface 3-knife cutterhead planer turning at 3,450 revolution per minute (RPM); a spindle moulder at $750 \mathrm{RPM}$; a bench drill at 2,880 RPM; a wood lathe at 1,780 RPM and a double drum belt sander with surface speed of 4.5 meters per second.

\section{B. Experimental Procedures}

\section{Design of Experiment}

The study was carried out using $2 \times 3$ and $4 \times 3$ Factorial Experiment in Completely Randomized Design representing the two depths of cut in the planing process, the other four cutting processes and the three density groups of wood samples. Each treatment combination was replicated three times.

\section{Sawing pattern and Cutting procedure}

Around seventy-year-old San Ramon palms were felled and cut to log lengths of five meters. The fust two logs were sawn to $25 \mathrm{~mm}$ thick by $125 \mathrm{~mm}$ wide lumber. The sawing pattern in, Figure 1 was employed to separate the low, medium and high density wood. ASTM standard procedure was followed in the cutting (Fig. 2) of samples for individual tests.

\section{Machining Test Procedures}

The standard machining test procedures of the American Society for Testing Materials, (ASTM: D-1666-64) were strictly observed in the conduct of the experiment. The quality of fmish were quantified by assigning numerical grades as follows: 1-specimen free from any defect; 2-very slight defect (easily removed by sanding); 3-average amount of labor and time to remove defect; 4more labor and time to remove defect; and 5-specimen deformed after removing defect. The basis of comparison was the percentage of specimen that were free from any defect.

\section{Analysis of Data}

The two Factor Factorial statistical analysis in Completely Randomized Design was employed to determine the significance of the accumulated data.

\section{RESULTS AND DISCUSSION}

The range of defect-free samples obtained by planing three density groups of coconut wood at two different depths of cut are presented in Table 1. Means of 72, 84 and 90 percent were obtained from low, medium and high density wood, respectively at cutting depth of $0.80 \mathrm{~mm}$. Subsequent planing of the respective samples to additional depth of $0.80 \mathrm{~mm}$ relatively raised the means to 86 , 94 and 99 percent tending to show that machinability of coconut wood improves with higher density and with increased depth of cut (Fig. 3). The same phenomenon was observed on the other machining; processes although the means generally vary in each density group (Table 2).

Statistical analysis revealed that the variation on the percentage of defect-free samples were significant at $1 \%$ level. However, the depth of cut has no significant effect on density which imply that cutting depth and density were independent variables in planing coconut wood. The resultant treatment means also showed significant differences among density groups between depths of cut.

The behaviour of coconut wood when subjected to other woodworking processes are reflected in Table 2. The variation on the percentage of defect-free samples resulting from the 
different machining processes and properties of wood were stastistically significant at $1 \%$ level. In contrast, the result indicate significant interaction between the machining process and density which signify that machinability of coconut wood depends upon its property and the processing method.

The treatment means generally increased among the three density groups with boring having the lowest mean of low dense wood, suggesting that machining defect would likely occur on this grade of coconut wood under this process (Figure 4). The resultant treatment means revealed significant differences among the three density groups of coconut wood. However, no significant variation was reflected in boring and shaping and in turning and sanding processes although the values were largely beyond satisfactory level.

Raised grain was apparent on low dense wood while fuzzy and chipped or tom grains were noted on medium and high densities respectively, notwithstanding the very slight degree of the defect which can be easily removed by sanding. Most of the defects occured on the edge or end of the finished product. In general, coconut wood exhibited excellent to fair machining qualities.

\section{CONCLUSION AND RECOMMENDATION}

The result of this study clearly indicates that coconut wood can be satisfactorily machined under a variety of machine operations normally encountered in commercial manufacturing practice. The quality of finish depends mainly on the processing method and density of the wood. As with other kinds of wood, excellent surface quality can be achieved with the right combination of machine speed and feed rate. Fast cutter speed coupled with appropriate feed rate usually produce good quality finish. Aside from excellent machinability, high density coconut wood exhibited dark brown and more attractive appearance.

Inspite of its durability, the necemary fmancial investment to secure tungsten carbide, its expensive maintenance equipment and the services of highly skilled technicians are limiting factors for unall scale wood. industries. Tipping or coating ordinary steel cutters with hard facing material. like stellite was proven possible and durable yet less expensive than carbide, hence is recommended. An experienced welder with ordinary machine shop equipment could adequately meet the maintenance requirement.

Low density coconut wood, for furniture should be air dried first to equilibrium moisture content and re-dried in a low temperature $\left(40^{-0} \mathrm{C}-50^{\circ} \mathrm{C}\right)$ kiln to rainimize seasoning defect. Splitting of high density coconut wood or bending of the nail could easily be overcome by boring the wood to a depth of about three fourths of its thickness before nailing. However, the diameter of the hole should be about $0.5 \mathrm{~mm}$ smaller than the diameter of the nail. 
Table 1.

Mean percentage of defect-free coconut wood relative to Depth of cut and desinty. ${ }^{1)}$

\begin{tabular}{|l|c|c|c|}
\hline \multirow{2}{*}{$\begin{array}{c}\text { Average Density } \\
\left(\mathrm{kg} / \mathrm{m}^{3}\right)\end{array}$} & \multicolumn{2}{|c|}{ Depth of Cut $(\mathrm{mm})$} & \multirow{2}{*}{$\begin{array}{c}\text { Density } \\
\text { Mean }\end{array}$} \\
\cline { 2 - 3 } & 0.80 & 1.60 & $81.0 \mathrm{a}$ \\
335 & 76.0 & 86.0 & $88.0 \mathrm{~b}$ \\
557 & 82.0 & 94.0 & $94.5 \mathrm{c}$ \\
\hline \multicolumn{1}{|c|}{ Depth-mean } & 90.0 & 99.0 & \multicolumn{2}{|c|}{$93.0^{\mathrm{b}}$ Grand mean 87.8} \\
\hline & $82.7^{\mathrm{a}}$ & Depth & Density x Depth \\
\hline Statistical Significance & Density & $* *$ & N.S. \\
Std. Error & 1.26 & 1.03 & N.S. \\
HSD 0.05 & 4.76 & 3.18 & N.S \\
0.01 & 6.40 & 4.45 & \\
C.V. $(\%)$ & 3.52 & & \\
\hline
\end{tabular}

1) Average of three (3) replicates. Means having the same letter are not significantly different at $5 \%$ level.

** Highly significant

N.S. Not significant

Table 2.

Mean percentage of defect free coconut wood relative to Machining process and density. ${ }^{1)}$

\begin{tabular}{|l|c|c|c|c|}
\hline \multicolumn{1}{|c|}{$\begin{array}{c}\text { Machining } \\
\text { Process (MP) }\end{array}$} & & & & \multirow{2}{*}{ MP-Mean } \\
\cline { 2 - 4 } & 335 & 557 & 749 & \\
\hline Boring & 68.0 & 80.7 & 91.3 & $80.0^{\mathrm{a}}$ \\
Shaping & 77.3 & 82.0 & 89.3 & $82.9^{\mathrm{a}}$ \\
Turning & 90.0 & 92.0 & 94.7 & $92.2^{\mathrm{b}}$ \\
Sanding & 93.0 & 98.0 & 98.7 & $96.7^{\mathrm{b}}$ \\
\hline Density-Mean & $82.2^{\mathrm{a}}$ & $88.2^{\mathrm{b}}$ & $93.5^{\mathrm{c}}$ Grand mean 88.0 \\
\hline & MP & Density & \multicolumn{2}{|c|}{ MP x Density } \\
\hline Statistical Sinificance & $* *$ & $* *$ & \multicolumn{2}{|c}{2.19} \\
STD Error & 1.27 & 1.10 & \multicolumn{2}{|c}{11.24} \\
HSD 0.05 & 4.95 & 3.88 & \multicolumn{2}{c}{13.50} \\
0.01 & 6.26 & 5.00 & \\
C.V. (\%) & 4.32 & \multicolumn{2}{|c}{} \\
\hline
\end{tabular}

1) Average of three (3) replicates. Means having the same letter are not significantly different at 5 level.

** Highly significant. 

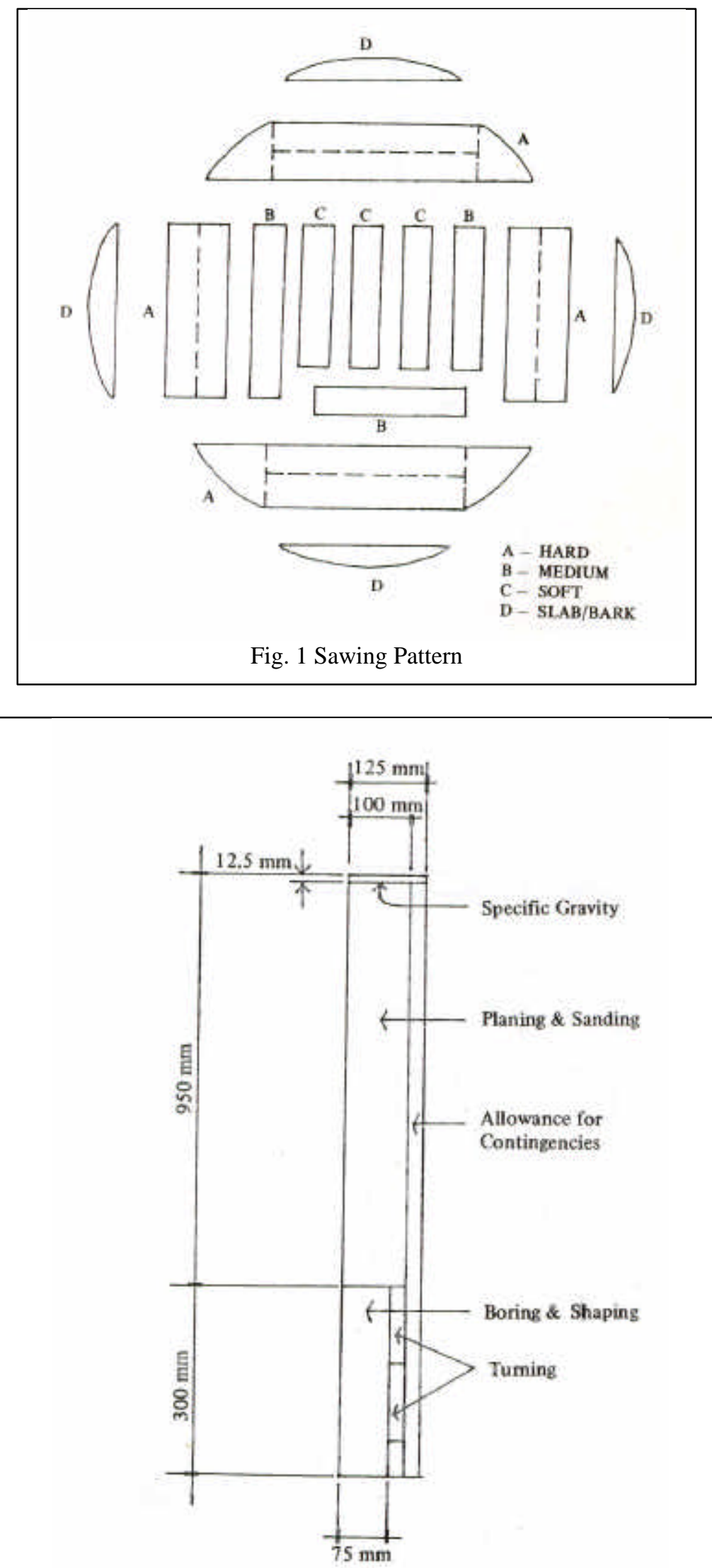

Fig. 2 Diagram for sawing lumber samples into smaller sample for Individual tests 

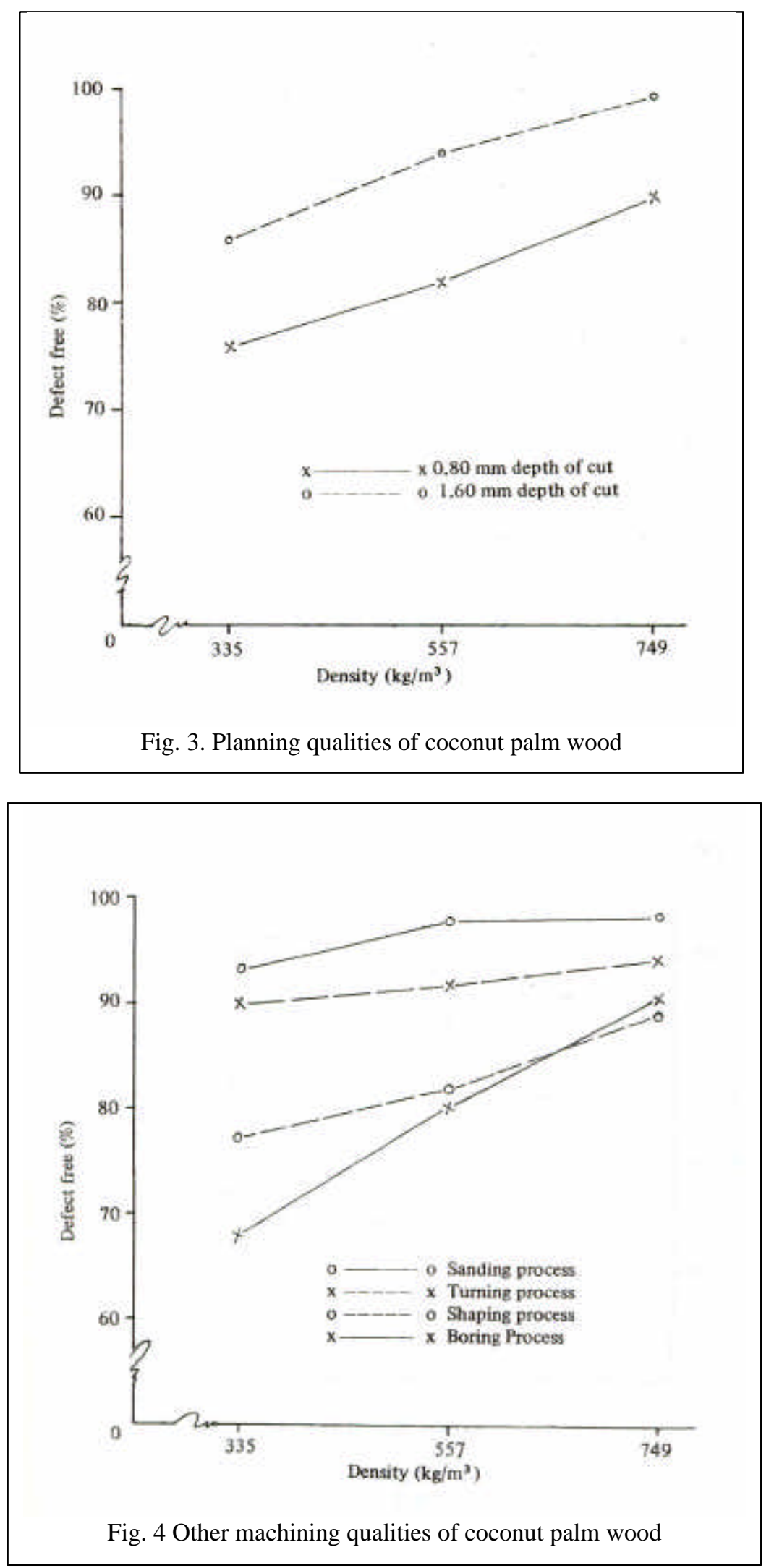


\section{REFERENCES}

Alston, A.S. 1976. Potential use of selected coconut wood for furniture and other decorative end-uses. Proceedings of Coconut Stem Utilization Seminar, Kingdom of Tonga, October, 1976.

American Society for Testing Materials, 1964. Standard method of conducting machining tests of wood and wood-based materials. ASTM Designation: D-1666-64.

Bergseng, K. 1976. Machining of coconut palm wood. Proceedings of Coconut Stem Utilization Seminar, Kingdom of Tonga. October, 1976.

Kininmonth, J.A. 1976. Drying sawn timber of coconut. Proceedings of Coconut Stem Utilization Seminar, Kingdom of Tonga. October, 1976.

Mcquire, A.J. 1979. Anatomical and Morphological features of coconut palm stem in relation to its utilization as an alternative wood source. Proceedings of Seminar on Coconut Wood Utilization, Manila and Zamboanga City. October, 1979.

Mendoza, A.M.R. 1979. The Philippine replanting program and the need for coconut wood utilization. Proceedings of Seminar on Coconut Wood Utilization, Manila and Zamboanga City. October, 1979.

Meylan, B.A. 1978. Density variation within Cocos nucifera L. stems. New Zealand Journal of Forestry Service 8 (3); 369-383.

Tamolang, F.N. and F.M. Lauricio, 1976. The strength and related properties of coconut trunk (Coco nucifera $L$ ). Proceedings of Coconut Stem Utilization Seminar, Kingdom of Tonga. October, 1976.

\section{Acknowledgement}

Grateful appreciation is sincerely extended to Messrs. Genovevo Gorit, Technician and

Daniel Ramos, Officer-in-Charge of the Woodworking Shop, Timber Utilization Division, Zamboanga Research Center for their assistance in the pireparation of the materials and evaluation of the finished products. 